CHRONIC OBSTRUCTIVE PULMONARY DISEASE

\title{
Decreased expression of interleukin 13 in human lung emphysema
}

\author{
A Boutten," M Bonay, ${ }^{*}$ S Laribe, G Leseche, Y Castier, V Leçon-Malas, M Fournier, G Durand, \\ M Aubier, M Dehoux, B Crestani
}

Thorax 2004;59:850-854. doi: 10.1136/thx.2004.025247

See end of article for authors' affiliations .....................

Correspondence to: $\operatorname{Dr} A$ Boutten, Laboratoire de Biochimie A, Hôpital Bichat-Claude Bernard, 46 rue Henri Huchard, 75870 Paris, Cedex 18, France; anne.boutten@bch.aphop-paris.fr

Received 19 March 2004 Accepted 24 June 2004
Background: The overexpression of interferon (IFN) $\gamma$ or interleukin (IL)-13 in the adult murine lung induces the development of changes that mirror human lung emphysema.

Methods: IL-13 and IFN $\gamma$ expression was determined in lung samples from five groups of patients: severe emphysema without $\alpha_{1}$-antitrypsin deficiency $(S E+, n=10)$; severe emphysema with $\alpha_{1}$-antitrypsin deficiency (SE-, $n=5)$; mild localised emphysema ( $M E, n=8)$; non-emphysema smokers (NE-S, $n=9)$, and non-emphysema non-smokers (NE-NS, $n=11$ ). Lung IL-13 and IFN $\gamma$ mRNA were analysed by RTPCR. Lung concentrations of IL-13 protein were assessed by ELISA.

Results: The expression of IFN $\gamma$ mRNA was similar in patients with or without emphysema. IL-13 mRNA was markedly decreased in the SE+ group compared with the SE- $(p=0.04), M E(p=0.02)$, and nonemphysema groups $(p=0.01)$. IL-13 mRNA correlated with forced expiratory volume in 1 second $(r=0.5$, $p=0.04)$ and arterial oxygen tension $(r=0.45, p=0.03)$ in emphysema patients. In contrast to the nonemphysematous lung, IL-13 protein was below the detection limit of the assay in most emphysematous lung homogenates.

Conclusion: The lung IL-13 content is reduced in patients with severe emphysema without $\alpha_{1}$-antitrypsin deficiency.
$E$ mphysema is a major component of the morbidity and mortality in chronic obstructive pulmonary disease (COPD) and represents an increasing health problem. ${ }^{1}$ Lung emphysema is defined pathologically by abnormal permanent enlargement of the air spaces distal to the terminal bronchiole accompanied by destruction of alveolar walls. Emphysema is a heterogeneous disease with regard to the degree of alveolar loss, the pattern of localisation in the lung, and the predisposing factors involved in its pathogenesis.

Although chronic cigarette smoking is the most important risk factor for emphysema, little is known about the mechanisms leading to alveolar destruction. The association of panacinar emphysema and a hereditary deficiency of $\alpha_{1}$-antitrypsin led to the development of the protease/ antiprotease hypothesis. ${ }^{2}$ Cigarette smoking may induce emphysema by stimulating neutrophils and alveolar macrophages to produce proteases within the lungs leading to a protease/antiprotease imbalance. ${ }^{45}$ The role of T lymphocytes has more recently been highlighted. ${ }^{2}{ }^{6}$ Increased susceptibility to emphysema was reported in inflammatory lung diseases characterised by the accumulation of activated $\mathrm{T}$ lymphocytes, such as AIDS and farmer's lung. ${ }^{78}$ Recently, targeted overexpression in the adult murine lungs of either interferon $\gamma$ (IFN $\gamma$ ) or interleukin 13 (IL-13), both cytokines produced by $\mathrm{T}$ lymphocytes and macrophages, has been shown to induce the development of changes that mirror human lung emphysema. ${ }^{9}{ }^{10}$ IL-13 or IFN $\gamma$ overexpression was associated with alveolar inflammation, increased lung volume, and a local imbalance in the protease/antiprotease expression.

These results led us to hypothesise that the overexpression of IL-13 and/or IFN $\gamma$ could contribute to the pathogenesis of human lung emphysema. To our knowledge, the involvement of these cytokines in human emphysema has never been investigated. A study was therefore undertaken to evaluate the pulmonary expression of IL-13 and IFN $\gamma$ in lung samples from patients with and without emphysema, according to their smoking status.

\section{METHODS \\ Patients}

Lung samples were obtained during surgery in adult patients (>18 years) from Beaujon University Hospital (Clichy, France) and Bichat-Claude Bernard University Hospital (Paris, France). Plasma concentration and $\alpha_{1}$-antitrypsin genotype were documented in all patients for the diagnosis of $\alpha_{1}$-antitrypsin deficiency.

Patients with lung emphysema

Twenty three patients with emphysema defined radiographically were included. All were active or ex-smokers (table 1). CT scans and pulmonary function tests were systematically documented. Eight patients were considered to have mild emphysema (ME) on the basis of localised emphysematous lesions on the CT scan and small changes in pulmonary function tests (table 2). They underwent either bullectomy $(n=5)$ or lobectomy $(n=3)$. No $\alpha_{1}$-antitrypsin deficiency was found in the ME group.

Fifteen patients had severe emphysema (SE), requiring surgery for lung transplantation $(\mathrm{n}=4)$ or lung volume reduction $(n=11)$. Pulmonary function tests showed severe airflow obstruction and lung distension (table 2). The SE patients were classified into two groups: (1) those with severe emphysema with $\alpha_{1}$-antitrypsin deficiency (SEgroup, $\mathrm{n}=5$, low $\alpha_{1}$-antitrypsin plasma concentration (range $0.25-0.8 \mathrm{~g} / \mathrm{l}$ ) and PI*ZZ genotype) and (2) those with severe emphysema without $\alpha_{1}$-antitrypsin deficiency (SE+ group, $\mathrm{n}=10$ ). One patient in the SE+ group was a current smoker. Patients with $\alpha_{1}$-antitrypsin deficiency had lower cumulative tobacco exposure than those without $\alpha_{1}$-antitrypsin

*Drs $A$ Boutten and $M$ Bonay contributed equally to the study. 
Table 1 Clinical characteristics of patients with and without emphysema

\begin{tabular}{|c|c|c|c|c|c|c|}
\hline & $\begin{array}{l}\text { Severe emphysema } \\
\text { without } \alpha_{1}-A T \\
\text { deficiency (SE+) } \\
(n=10)\end{array}$ & $\begin{array}{l}\text { Severe emphysema } \\
\text { with } \alpha_{1}-\mathrm{AT} \\
\text { deficiency (SE-) } \\
(\mathrm{n}=5)\end{array}$ & $\begin{array}{l}\text { Mild emphysema } \\
\text { (ME) } \\
(\mathrm{n}=8)\end{array}$ & $\begin{array}{l}\text { Non-emphysema } \\
\text { smokers (NE-S) } \\
(\mathrm{n}=9 \text { ) }\end{array}$ & $\begin{array}{l}\text { Non-emphysema } \\
\text { non-smokers (NE-NS) } \\
\text { ( } \mathrm{n}=11 \text { ) }\end{array}$ & $\begin{array}{l}\text { Between group } \\
\text { differences }\end{array}$ \\
\hline Age (years) & $62.4(7.5)$ & $58.4(10.1)$ & $53.7(11.0)$ & $57.0(11.2)$ & $54.7(19)$ & NS \\
\hline Sex ratio $(F / M)$ & $1 / 9$ & $2 / 3$ & $0 / 8$ & $0 / 9$ & $2 / 9$ & NS \\
\hline Smoking (pack years) & $49.0(14.8)$ & $19.0(6.5)^{*} \dagger$ & $49.3(30.3)$ & $35.0(14.9)$ & 0 & $p<0.001$ \\
\hline $\begin{array}{l}\text { Time since smoking } \\
\text { cessation (years) }\end{array}$ & $7.0(7.1) \S$ & $13.4(8.6) \dagger \ddagger$ & $1.0(2.6)$ & $3.2(6.7)$ & NA & $\mathrm{p}<0.001$ \\
\hline $\begin{array}{l}\text { Active smokers/ex- } \\
\text { smokers }\end{array}$ & $1 / 9$ & $0 / 5$ & $6 / 2$ & $7 / 2$ & NA & $\mathrm{p}<0.001$ \\
\hline
\end{tabular}

deficiency and ME patients (table 1). They also stopped smoking earlier in the course of the disease than patients with ME. Tissue samples were taken from the resected parenchyma in a macroscopically emphysematous region. Twelve patients with emphysema were receiving corticosteroids, either oral (two in SE+ group) or inhaled $(\mathrm{n}=10$; six in $\mathrm{SE}+$ group, three in SE- group, one in ME group). No patient had asthma and one had seasonal rhinitis.

\section{Non-emphysema patients}

Normal tissue was obtained from 20 non-emphysema patients. Nine patients were smokers (non-emphysema smoker group, NE-S) and 11 were non-smokers (nonemphysema non-smoker group, NE-NS). NE-S patients were undergoing surgery for the resection of a localised primary lung carcinoma $(n=8)$ or a benign lesion $(n=1)$. NE-NS patients were undergoing surgery for the resection of a localised primary lung carcinoma $(n=6)$, lung metastases $(n=2)$, or a benign lesion $(n=3)$. Tissue samples were taken at a site distant from the pathological process and without macroscopic or microscopic evidence of emphysema. NE-S patients had mild to moderate changes in pulmonary functions tests (table 2). Two patients in the NE-S group received inhaled corticosteroids. No significant difference was observed between NE-S, ME and SE+ groups for cumulative tobacco exposure (table 1). No patient had asthma and one had seasonal rhinitis. No difference was observed between groups for age and sex ratio (table 1).

\section{Processing of lung samples}

Histological characterisation of the underlying processes was performed to check the features of emphysematous or normal lungs. Lung samples (about $0.2 \mathrm{~cm}^{3}$ ) were immediately frozen in liquid nitrogen and stored at $-80^{\circ} \mathrm{C}$ until RNA or protein analysis and histological evaluation.
Isolation of RNA and cDNA synthesis

To extract total RNA from the lung, $100 \mathrm{mg}$ of frozen lung tissue was homogenised in $1 \mathrm{ml}$ TRIzol reagent (Invitrogen, Cergy Pontoise, France) with Ultra-Turrax T25 (Ika Works, Staufen, Germany) according to the manufacturer's procedure. One $\mu \mathrm{g}$ of total RNA was reverse transcribed in a thermocycler (Uno II, Biometra, Voisins le Bretonneux, France) with superscript II reverse transcriptase (Invitrogen), $20 \mathrm{mM}$ of each desoxyribonucleoside triphosphate (dNTP) and $50 \mathrm{U}$ random hexanucleotides primers (Invitrogen) for 1 hour at $42^{\circ} \mathrm{C}$. The reaction was stopped by heating at $95^{\circ} \mathrm{C}$ for 4 minutes and samples (final volume $20 \mu \mathrm{l}$ ) were stored at $-80^{\circ} \mathrm{C}$ until amplification.

\section{Quantification of cDNAs}

Each sample was analysed for the expression of IL-13, IFN $\gamma$, and porphobilinogen desaminase (PBGD) as a housekeeping gene. ${ }^{11}$ For amplification of cDNAs, reaction mixtures (final volume $25 \mu \mathrm{l}$ ) contained: $\mathrm{MgCl}_{2}(1.5 \mu \mathrm{M}$ for IL-13, PBGD, and $0.5 \mu \mathrm{M}$ for IFN $\gamma$ ); $\%$ formamide only for IL-13, and PBGD; $200 \mu \mathrm{M}$ of each dNTP; 12 pmol of each specific oligonucleotide primer pair (table 3), and cDNA. This mixture was heated at $94^{\circ} \mathrm{C}$ for 5 minutes, then $2.5 \mathrm{U}$ Taq Polymerase (Roche Diagnostics, Meylan, France) was added. PCR was performed as follows: denaturation, $94^{\circ} \mathrm{C}$ for 30 seconds; annealing, $60^{\circ} \mathrm{C}$ (for PBGD) or $55^{\circ} \mathrm{C}$ (IL-13, IFN $\gamma$ ) for 30 seconds; extension, $72^{\circ} \mathrm{C}$ for 40 seconds. For each gene we checked that the amplification process was performed during the exponential phase of the replication ( 34 cycles for IL-13, 35 for IFN $\gamma$ and PBGD) and that we could detect proportional signal intensity on serial dilutions of mRNA from lung homogenates. Negative controls were included in all experiments and always gave negative results. Amplification products were analysed by electrophoresis and visualised by ethidium bromide staining. The size of the amplification products was 159, 130 and 338 bp for IL-13,

Table 2 Pulmonary function tests of patients with and without emphysema

\begin{tabular}{|c|c|c|c|c|c|c|}
\hline & $\begin{array}{l}\text { Severe emphysema } \\
\text { without } \alpha_{1}-A T \\
\text { deficiency }(\mathrm{SE}+) \\
(\mathrm{n}=10)\end{array}$ & $\begin{array}{l}\text { Severe emphysema } \\
\text { with } \alpha_{1} \text {-AT } \\
\text { deficiency (SE-) } \\
(\mathrm{n}=5 \text { ) }\end{array}$ & $\begin{array}{l}\text { Mild emphysema } \\
\text { (ME) } \\
(n=8)\end{array}$ & $\begin{array}{l}\text { Non-emphysema } \\
\text { smokers (NE-S) } \\
(\mathrm{n}=9 \text { ) }\end{array}$ & $\begin{array}{l}\text { Non-emphysema } \\
\text { non-smokers } \\
\text { (NE-NS) } \\
(\mathrm{n}=11)\end{array}$ & $\begin{array}{l}\text { Between group } \\
\text { differences }\end{array}$ \\
\hline $\mathrm{FEV}_{1}$ (\% pred) & $23.6(7.8)^{*} \dagger \ddagger$ & $24.8(12.7)^{*} \dagger \ddagger$ & $66.6(22.5)$ & $70(20.3)$ & $80.4(11.4)$ & $\mathrm{p}<0.001$ \\
\hline $\mathrm{FEV}_{1} / \mathrm{FVC}$ & $40.7(6.2)^{*}+\ddagger$ & $39.8(7.8)^{*} † \ddagger$ & $59.6(14.3) \ddagger$ & $67.6(14.0) \neq$ & $88.3(11.7)$ & $\mathrm{p}<0.001$ \\
\hline RV (\% pred) & $252.7(50.4)^{*} \dagger \ddagger$ & $278.8(92)^{*} \dagger \neq$ & $155(49.4) \ddagger$ & $125.7(20)$ & $88.9(22.3)$ & $\mathrm{p}<0.001$ \\
\hline TLC (\% pred) & $130.5(14)^{*} \dagger \ddagger$ & $138.8(21.5)^{\star} \dagger \ddagger$ & $109.1(15.3) \ddagger$ & $101.2(10.4) \ddagger$ & $81.5(13.2)$ & $\mathrm{p}<0.001$ \\
\hline $\mathrm{PaO}_{2}(\mathrm{kPa})$ & $8.7(1.2)^{*} \dagger \ddagger$ & $8.3(1.0)^{*}+\ddagger$ & $10.4(0.8)$ & $10.8(2.0)$ & $11.5(1.0)$ & $p<0.001$ \\
\hline $\mathrm{PaCO}_{2}(\mathrm{kPa})$ & $5.5(0.7)$ & $4.9(0.3)$ & $5.5(0.6)$ & $5.3(1.0)$ & $5.5(0.4)$ & NS \\
\hline
\end{tabular}

${ }^{*} \mathrm{p}<0.01 \vee \mathrm{ME} ; \mathrm{tp}<0.01 \vee \mathrm{NE}-\mathrm{S} ; \mathrm{tp}<0.01 \vee \mathrm{NE}-\mathrm{NS}$ (Mann-Whitney U test)

$\mathrm{NS}$, non-significant; $\mathrm{PaO}_{2}$, arterial oxygen pressure; $\mathrm{PaCO}_{2}$, arterial carbon dioxide pressure; $\mathrm{FEV}$, forced expiratory volume in 1 second; RV, residual volume; FVC, forced vital capacity; TLC, total lung capacity. 
IFN $\gamma$, and PBGD, respectively. The specificity of the amplified sequence was checked using restriction enzymes (Ozyme Biolabs, Saint Quentin en Yvelines, France) MboI, Fnu4HI, respectively, for IL-13 and IFN $\gamma$. The signal intensity of each amplified product was quantified under ultraviolet light with a charge coupled device (CCD) camera using an image analyser (Gel-Analyst, Iconix, Santa Monica, CA, USA). The expression of IL-13 and IFN $\gamma$ mRNA was expressed for each sample as the ratio of the PBGD gene. This method allowed for a semi-quantitative analysis of the RT-PCR. All steps in the procedure (reverse transcription, amplification, quantification) were performed in the same run for the 43 samples (23 patients with emphysema and 20 non-emphysema patients), blinded to diagnosis.

\section{IL- 13 concentration in lung homogenates}

$100 \mathrm{mg}$ of lung samples were homogenised with $0.5 \mathrm{ml}$ PBS containing $200 \mu \mathrm{M}$ phenylmethylsulfonyl fluoride, $1 \mathrm{mg} / \mathrm{ml}$ leupeptin, and $1 \mathrm{mg} / \mathrm{ml}$ aprotinin. The homogenates were centrifuged at $10000 \mathrm{~g}$ for 10 minutes at $4^{\circ} \mathrm{C}$ to remove tissue fragments and the supernatants were collected and stored at $-80^{\circ} \mathrm{C}$. IL-13 protein was measured in lung homogenates (Quantikine, RD Systems, Abingdon, UK; detection limit $60 \mathrm{pg} / \mathrm{ml}$, intra-assay coefficient of variation $<6 \%$, interassay $<10 \%)$ from 30 out of 43 patients when enough lung sample was available (7 SE+, $2 \mathrm{SE}-, 6 \mathrm{ME}, 6 \mathrm{NE}-\mathrm{S}, 9$ NE-NS).

In order to exclude matrix artefacts caused by interfering substances in lung homogenates, we serially diluted lung samples and confirmed the linearity of the response. In preliminary experiments we checked that the preparation of lung homogenates did not alter IL-13. Three emphysematous lung samples were spiked with recombinant human IL-13, incubated for 1 hour at room temperature, and analysed by ELISA. We confirmed that recombinant IL-13 was not modified by this treatment.

\section{Statistical analysis}

Data were analysed by Statview software (Abacus Concepts Inc) and are shown as mean (SD) values. Between group differences were first assessed by non-parametric analysis of variance (Kruskal-Wallis test). In the case of global significant difference between two groups, comparisons were assessed by the non-parametric Mann-Whitney $U$ test. Correlations were assessed by the Spearman's rank order test and categorical data were analysed using the $\chi^{2}$ test. A $\mathrm{p}$ value of $<0.05$ was considered significant.

The study was approved by the local ethical committee.

\section{RESULTS}

\section{Lung IFN $\gamma$ mRNA expression}

IFN $\gamma$ was detected in the lungs of all the patients and considerable variability was observed in the transcript levels in patients both with and without emphysema (fig 1). No difference was observed according to the presence or severity of emphysema, $\alpha_{1}$-AT deficiency, and smoking status. There was no correlation with age, cumulative tobacco exposure,

\begin{tabular}{lll}
$\begin{array}{l}\text { Table } 3 \\
\text { of CDNAs }\end{array}$ & Sequence of primer pairs used for amplification \\
\hline IL-13 & 5' CAA CAT CAC CCA & 5' CAG AAT CCG CTC AGC \\
& GAA CCA GAA G & ATC CTC \\
IFN- $\gamma$ & 5' CGA GAT GAC TTC & 5' CCT TTा TCG CTT CCC TGT \\
& GAA AAG CTG ACT & TTा A \\
PBGD & 5' CTG GTA ACG GCA & 5' GCA GAT GGC TCC GAT \\
& ATG CGG CT & GGT GGT GA \\
\hline
\end{tabular}

IL-13, interleukin 13; IFN $\gamma$, interferon $\gamma$; PBGD, porphobilinogen desaminase.

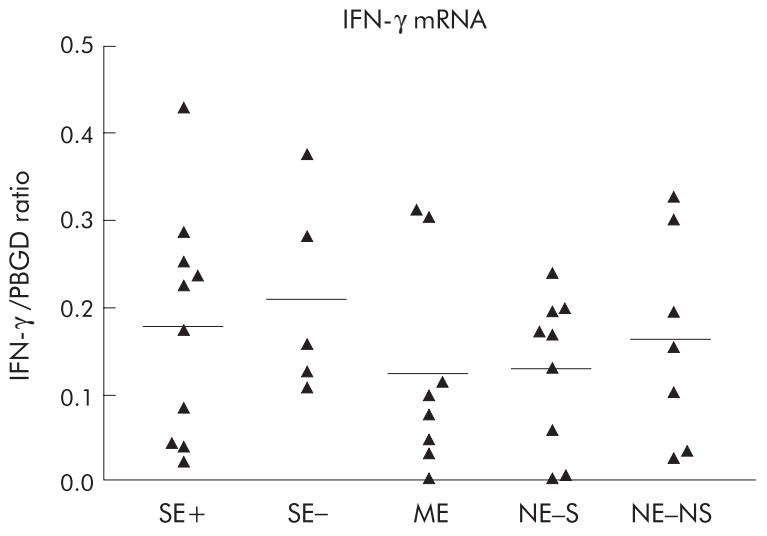

Figure 1 Expression of IFN $\gamma$ mRNA in lung tissue from the five patient groups as a ratio to porphobilinogen desaminase (PBGD) in arbitrary units. Individual and mean values (horizontal bars) are presented. SE+, severe emphysemas without $\alpha_{1}$-AT deficiency, SE-, severe emphysema with $\alpha_{1}$-AT deficiency, ME, mild emphysema; NE-S and NE-NS, nonemphysema smokers and non-smokers. The four missing values in the NE-NS group are related to unsuccessful cDNA quantification.

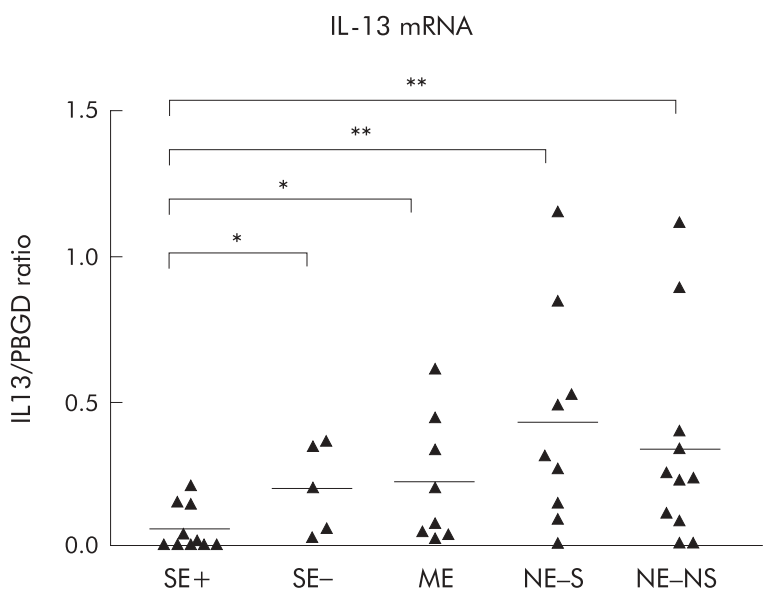

Figure 2 Expression of IL-13 mRNA in lung tissue from patients with or without emphysema as a ratio to porphobilinogen desaminase (PBGD) in arbitrary units. Individual and mean values (horizontal bars) are presented. ${ }^{*} p<0.05,{ }^{* *} p=0.01$. SE+, severe emphysema without $\alpha_{1}$-AT deficiency; SE-, severe emphysema with $\alpha_{7}$-AT deficiency; ME, mild emphysema; NE-S and NE-NS, non-emphysema smokers and nonsmokers.

period since smoking cessation, use of inhaled corticosteroids, pulmonary function tests, and arterial blood gases in any group.

\section{Lung IL- 13 mRNA expression}

IL-13 mRNA expression was significantly different between the groups as assessed by the Kruskal-Wallis test $(p=0.02)$. Lung IL-13 mRNA levels were low or undetectable in all patients in the SE+ group (fig 2). The mean value was significantly lower in SE+ patients than in all other groups $(\mathrm{p}=0.04 v \mathrm{SE}-; \mathrm{p}=0.02 v \mathrm{ME} ; \mathrm{p}=0.01 v \mathrm{NE}-\mathrm{S} ; \mathrm{p}=0.01 v$ NE-NS). IL-13 mRNA levels in ME and SE- patients did not differ significantly from non-emphysema patients. IL-13 mRNA levels did not differ between non-emphysema smokers (NE-S) and non-smokers (NE-NS). No correlation was found between IL-13 mRNA and age, period since smoking cessation, use of inhaled corticosteroids, or body mass index (BMI). There was no correlation with cumulative 
tobacco exposure in any of the emphysema patients, nonemphysema smokers, or in all smokers. A significant correlation was found between IL-13 expression and pulmonary function tests in the whole population (RV: $r=-0.38, \mathrm{p}=0.03$; FVC: $r=+0.31, \mathrm{p}=0.01 ; \mathrm{FEV}_{1}: r=+0.4$, $\mathrm{p}=0.002 ; \mathrm{FEV}_{1} / \mathrm{FVC}: r=+0.26, \mathrm{p}=0.01 ; \mathrm{PaO}_{2}: r=+0.26$, $\left.\mathrm{p}=0.005 ; \mathrm{SaO}_{2}: r=+0.27, \mathrm{p}=0.02\right)$. Correlations between IL13 mRNA expression and $\mathrm{FEV}_{1}$ or $\mathrm{PaO}_{2}$ persisted when emphysema patients were considered separately (FVC: $r=+0.55, \mathrm{p}=0.05 ; \mathrm{FEV}_{1}: r=+0.5, \mathrm{p}=0.04 ; \mathrm{PaO}_{2}: r=+0.45$, $\mathrm{p}=0.03)$.

\section{IL- 13 protein concentration in lung homogenates}

IL-13 protein was measured in lung homogenates (fig 3 ). The proportion of samples with undetectable IL-13 was compared in patients with and without emphysema ( $\chi^{2}$ test). IL-13 concentrations were below the detection limit of the assay in 11 of 15 emphysema samples and in four of 15 nonemphysema samples $(\mathrm{p}=0.01)$.

\section{DISCUSSION}

The main results of our study are that (1) the expression of IFN $\gamma$ mRNA is similar in emphysematous and non-emphysematous lungs and (2) the expression of IL-13 mRNA in the human lung is reduced in patients with severe emphysema without $\alpha_{1}$-AT deficiency and is associated with the absence of detectable IL-13 protein in most emphysematous lung homogenates.

To our knowledge, IFN $\gamma$ mRNA expression has never been studied in human emphysema. Since the overexpression of IFN $\gamma$ in the murine lung induces changes that mimic emphysema, ${ }^{9}$ we hypothesised that increased lung expression of IFN $\gamma$ might be related to the presence and severity of emphysema in humans. However, we found no difference in IFN $\gamma$ mRNA expression between patients with or without emphysema. As IFN $\gamma$ mRNA levels were not different in mild and severe emphysema, our results do not suggest the involvement of IFN $\gamma$ in the initial phase of the condition. We further attempted to measure IFN $\gamma$ protein in lung homogenates but, unfortunately, we obtained non-reproducible results using a commercially available ELISA.

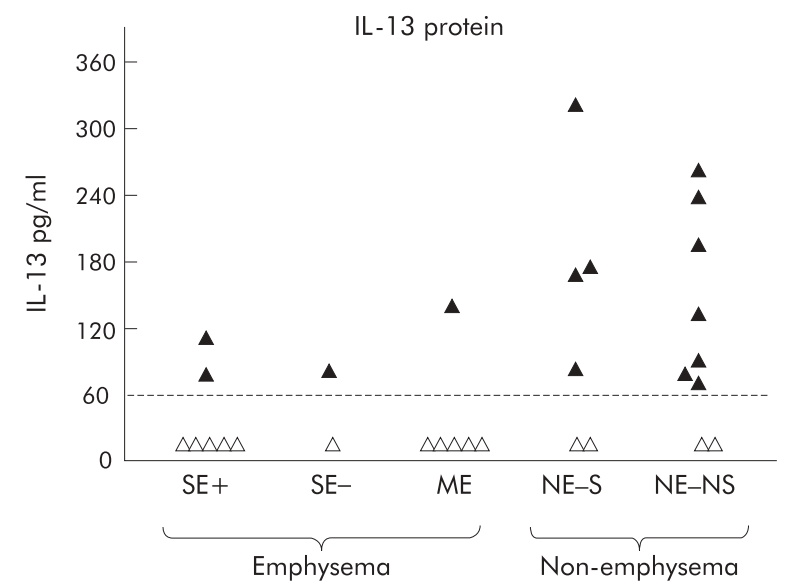

Figure 3 IL-13 protein concentrations in lung tissue from patients with or without emphysema. The horizontal line represents the detection limit $(60 \mathrm{pg} / \mathrm{ml})$. Open triangles: undetectable IL-13, closed triangles: detectable IL-13 concentrations. The proportion of samples with undetectable IL-13 was significantly higher in patients with emphysema than in those with no emphysema ( $p=0.01, \chi^{2}$ test). $\mathrm{SE}+$, severe emphysema without $\alpha_{1}$-AT deficiency, $\mathrm{SE}-$, severe emphysema with $\alpha_{-}$-AT deficiency; ME, mild emphysema; NE-S and NE-NS, nonemphysema smokers and non-smokers.
We show for the first time that lung IL-13 mRNA and protein content are significantly decreased in patients with severe emphysema. These results were unexpected in view of the murine model of IL-13 overexpression. Zheng et a $l^{10}$ have shown that IL-13 overexpression in the adult murine lung causes alterations with air space enlargement that mirror human lung emphysema. In that model the inactivation of either MMP-9 or MMP-12 genes inhibited the development of emphysema. ${ }^{12}$ However, this animal model does not strictly reproduce human tobacco induced emphysema. For example, IL-13 overexpression induces the fast development of emphysema (within 7 days), a time course very different from the slow development of emphysema in humans.

Our data suggest that lung IL-13 expression in patients with emphysema was not directly related to tobacco exposure. Indeed, lung IL-13 mRNA and protein levels were similar in the NE-S and NE-NS groups, and the cumulative tobacco exposure was similar in the SE+, ME, and NE-S groups despite different levels of lung IL-13 mRNA. IL-13 mRNA levels were higher in patients with $\alpha_{1}$-AT deficiency (SE- group) than in those without $\alpha_{1}$-AT deficiency (SE+ group). This could be related to a different pathophysiology, although we cannot speculate further. ${ }^{13}$

It is well known that emphysema affects different lung regions to a varying extent. In our study only one tissue sample from surgically resected material was available for examination for each patient, so the cytokine expression may reflect regional disease activity. Moreover, biopsies from ME patients were obtained either from bullectomy or lobectomy where histological lesions may be different. Lung biopsy specimens from patients with severe emphysema had no features of end stage fibrosis. Hancock et $a l^{14}$ have shown that lung IL-13 mRNA levels are increased in patients with lung fibrosis. We assessed IL-13 mRNA expression in biopsy specimens of lung fibrosis. As previously described, ${ }^{14}$ IL-13 mRNA levels were similar or higher in lung fibrosis than in non-emphysema patients (data not shown). This result suggests that decreased IL-13 expression is a specific characteristic of severe emphysema. Because the patients could only be evaluated at one time point in the course of their disease, we chose to include age matched patients with different degrees of emphysema: severe emphysema, mild emphysema, and smokers without CT evidence of emphysema. This allowed the study of less extensive disease and the differentiation between emphysema related and tobacco related events.

What is the mechanism for the decreased expression of IL13 in severe emphysema? IL-13 is produced mainly by CD4+ and CD8+ activated T cells. ${ }^{15}$ Recent studies have shown a dramatic increase in all cell types including $\mathrm{T}$ lymphocytes in the lungs during severe emphysema. ${ }^{16}$ Taken together with our results, this suggests that IL-13 expression in lung T lymphocytes is dramatically reduced in severe emphysema. It has recently been reported that the development of emphysema in TNF $\alpha$ transgenic mice was associated with a lung Thl phenotype, ${ }^{17}$ and that human subjects with COPD were characterised by Thl-like immune response of peripheral blood CD4+ T cells. ${ }^{18}$ Reduced IL-13 expression with unchanged expression of IFN $\gamma$ might therefore be explained by differentiation of lymphocytes towards a Thl phenotype. Alternatively, alveolar macrophages are possible cell sources of IL-13 in the lung, ${ }^{14}$ but it is unknown whether IL-13 production by alveolar macrophages is reduced in emphysema.

We found that IL-13 expression was positively correlated with pulmonary function. IL-13 mRNA correlated with lung distension (RV), airway obstruction $\left(\mathrm{FEV}_{1}\right.$ and $\left.\mathrm{FEV}_{\mathrm{l}} / \mathrm{FVC}\right)$ and impaired gas exchange $\left(\mathrm{PaO}_{2}\right)$. These results confirm the link between IL-13 expression and the severity of emphysema. 
Interestingly, some studies have evaluated the link between IL-13 gene polymorphisms and COPD. A higher frequency of the $-1055 \mathrm{~T}$ IL-13 promoter polymorphism has been reported in COPD than in smokers with normal lung function, but the effect of this polymorphism on IL-13 expression is not yet known. ${ }^{19} \mathrm{He}$ and colleagues $^{20}$ have evaluated five different polymorphisms in the IL-13 or IL-13 receptor genes and none was associated with a rapid decline in lung function in smokers.

A number of published papers support the hypothesis of a protective role for IL-13 against the development of emphysema in the lung: (1) IL-13 has a beneficial effect on the protease/antiprotease imbalance in different models; ${ }^{15} 2122$ (2) IL-13 mediates anti-oxidant effects through the activation of heme oxygenase; ${ }^{23}$ (3) IL-13 has anti-apoptotic properties on epithelial and endothelial cells, ${ }^{23}$ a key event in the development of emphysema; ${ }^{24-27}$ (4) IL-13, as opposed to IFN $\gamma$ and tumour necrosis factor $\alpha(\mathrm{TNF} \alpha)$, increases fibroblast growth and collagen synthesis; (5) IL-13 is also a potent inducer and activator of transforming growth factor (TGF) $\beta_{1}$, a main modulator of lung remodelling and repair ${ }^{28}$ involved in the physiopathology of emphysema in mice. ${ }^{29} 30$ Thus, reduced IL-13 production in smokers could favour protease imbalance, oxidant injury, apoptosis, and alveolar defective repair, finally contributing to the development of emphysema.

We conclude that severe emphysema is associated with decreased lung IL-13 mRNA and protein content. Further studies are required to determine whether IL-13 is decreased earlier in the course of the disease and whether low IL-13 production is a risk factor for emphysema development.

\section{ACKNOWLEDGEMENTS}

The authors thank Joëlle Marchal for helpful technical assistance.

\section{Authors' affiliations \\ A Boutten, M Bonay, M Fournier, M Aubier, M Dehoux, B Crestani, INSERM U 408, Hôpital Bichat-Claude Bernard, Paris, France M Aubier, B Crestani, Service de Pneumologie, Hôpital Bichat-Claude Bernard, Paris, France \\ M Bonay, Service de Physiologie-Explorations Fonctionnelles, Hôpital Bichat-Claude Bernard, Paris, France \\ A Boutten, $\mathbf{S}$ Laribe, V Leçon-Malas, G Durand, M Dehoux, Service de Biochimie A, Hôpital Bichat-Claude Bernard, Paris, France \\ M Fournier, Service de Pneumologie, Hôpital Beaujon, Assistance Publique-Hôpitaux de Paris, France \\ G Leseche, Y Castier, Service de Chirurgie Thoracique, Hôpital Beaujon, Assistance Publique-Hôpitaux de Paris, France \\ REFERENCES \\ 1 Barnes PJ. Chronic obstructive pulmonary disease. N Engl J Med 2000;343:269-80. \\ 2 Finkelstein R, Fraser RS, Ghezzo H, et al. Alveolar inflammation and its relation to emphysema in smokers. Am J Respir Crit Care Med 1995:152:1666-72. \\ 3 Mahadeva R, Lomas DA. Genetics and respiratory disease - 2: Alpha 1- antitrypsin deficiency, cirrhosis and emphysema. Thorax 1998;53:501-5. \\ 4 Shapiro SD. The macrophage in chronic obstructive pulmonary disease. Am J Respir Crit Care Med 1999;160:S29-32.}

5 Hogg JC, Senior RM. Chronic obstructive pulmonary disease - 2: Pathology and biochemistry of emphysema. Thorax 2002;57:830-4.

6 Turato $G$, Zuin R, Miniati $M$, et al. Airway inflammation in severe chronic obstructive pulmonary disease: relationship with lung function and radiologic emphysema. Am J Respir Crit Care Med 2002;166:105-10.

7 Diaz PT, King MA, Pacht ER, et al. Increased susceptibility to pulmonary emphysema among HIV-seropositive smokers. Ann Intern Med 2000; 132:369-72.

8 Erkinjuntti-Pekkanen R, Rytkonen $\mathrm{H}$, Kokkarinen Jl, et al. Long-term risk of emphysema in patients with farmer's lung and matched control farmers. Am J Respir Crit Care Med 1998;158:662-5.

9 Wang Z, Zheng T, Zhu Z, et al. Interferon gamma induction of pulmonary emphysema in the adult murine lung. J Exp Med 2000;192:1587-600.

10 Zheng T, Zhu Z, Wang Z, et al. Inducible targeting of IL-13 to the adult lung causes matrix metalloproteinase- and cathepsin-dependent emphysema. J Clin Invest 2000;106: 1081-93.

11 Finke J, Fritzen R, Ternes $P$, et al. An improved strategy and a useful housekeeping gene for RNA analysis from formalin-fixed, paraffin-embedded tissues by PCR. Biotechniques 1993;14:448-53.

12 Lanone S, Zheng T, Zhu Z, et al. Overlapping and enzyme-specific contributions of matrix metalloproteinases-9 and -12 in IL-13-induced inflammation and remodeling. J Clin Invest 2002;1 10:463-74.

13 DeMeo DL, Silverman EK. Alpha-1-antitrypsin deficiency - 2: Genetic aspects of alpha(1)-antitrypsin deficiency: phenotypes and genetic modifiers of emphysema risk. Thorax 2004;59:259-64.

14 Hancock A, Armstrong L, Gama R, ef al. Production of interleukin 13 by alveolar macrophages from normal and fibrotic lung. Am J Respir Cell Mol Biol 1998; 18:60-5.

15 Wynn TA. IL-13 effector functions. Annu Rev Immunol 2003;21:425-56.

16 Retamales I, Elliott WM, Meshi B, et al. Amplification of inflammation in emphysema and its association with latent adenoviral infection. Am J Respir Crit Care Med 2001; 164:469-73.

17 Fujita M, Shannon JM, Irvin CG, et al. Overexpression of tumor necrosis factor-alpha produces an increase in lung volumes and pulmonary hypertension. Am J Physiol Lung Cell Mol Physiol 2001;280:L39-49.

18 Majori M, Corradi M, Caminati A, et al. Predominant TH1 cytokine pattern in peripheral blood from subjects with chronic obstructive pulmonary disease. J Allergy Clin Immunol 1999;103:458-62.

19 van der Pouw Kraan TC, Kucukaycan M, Bakker AM, et al. Chronic obstructive pulmonary disease is associated with the $-1055 \mathrm{IL}-13$ promoter polymorphism. Genes Immun 2002;3:436-9.

$20 \mathrm{He} \mathrm{JQ}$, Connett JE, Anthonisen NR, et al. Polymorphisms in the IL13, IL13RAI, and IL4RA genes and rate of decline in lung function in smokers. Am J Respir Cell Mol Biol 2003;28:379-85.

21 Tardif G, Pelletier JP, Dupuis M, et al. Collagenase 3 production by human osteoarthritic chondrocytes in response to growth factors and cytokines is a function of the physiologic state of the cells. Arthritis Rheum 1999;42: 1147-58.

22 Jovanovic D, Pelletier JP, Alaaeddine N, et al. Effect of IL-13 on cytokines, cytokine receptors and inhibitors on human osteoarthritis synovium and synovial fibroblasts. Osteoarthritis Cartilage 1998;6:40-9.

$23 \mathrm{Ke} B$, Shen XD, Zhai $Y$, et al. Heme oxygenase 1 mediates the immunomodulatory and antiapoptotic effects of interleukin 13 gene therapy in vivo and in vitro. Hum Gene Ther 2002;13:1845-57.

24 Imai K, D'Armiento J. Differential gene expression of sFRP-1 and apoptosis in pulmonary emphysema. Chest 2002;121(Suppl 3):S7

25 Kasahara Y, Tuder RM, Cool CD, et al. Endothelial cell death and decreased expression of vascular endothelial growth factor and vascular endothelial growth factor receptor 2 in emphysema. Am J Respir Crit Care Med 2001; 163:737-44.

26 Segura-Valdez L, Pardo A, Gaxiola M, et al. Upregulation of gelatinases A and $B$, collagenases 1 and 2 , and increased parenchymal cell death in COPD. Chest 2000;1 17:684-94.

27 Lucey EC, Keane J, Kuang PP, et al. Severity of elastase-induced emphysema is decreased in tumor necrosis factor-alpha and interleukin-1 beta receptordeficient mice. Lab Invest 2002:82:79-85.

28 Lee CG, Homer RJ, Zhu Z, et al. Interleukin-13 induces tissue fibrosis by selectively stimulating and activating transforming growth factor $\beta_{1}$.J Exp Med 2001;194:809-21.

29 Morris DG, Huang X, Kaminski N, et al. Loss of integrin alpha(v)beta6mediated TGF-beta activation causes Mmp12-dependent emphysema. Nature 2003;422:169-73.

30 Neptune ER, Frischmeyer PA, Arking DE, et al. Dysregulation of TGF-beta activation contributes to pathogenesis in Marfan syndrome. Nat Genet 2003;33:407-11. 